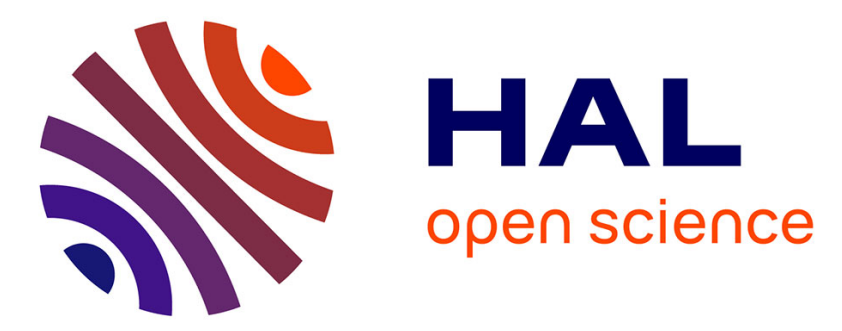

\title{
Boron-MgO composite as an X-ray transparent pressure medium in the multi-anvil apparatus
}

Longjian Xie, Akira Yoneda, Fang Xu, Yuji Higo, Chao Wang, Yoshinori Tange, Andrew King, Daniele Antonangeli, Guillaume Morard, Nicolas

Guignot

\section{To cite this version:}

Longjian Xie, Akira Yoneda, Fang Xu, Yuji Higo, Chao Wang, et al.. Boron-MgO composite as an $\mathrm{X}$-ray transparent pressure medium in the multi-anvil apparatus. Review of Scientific Instruments, 2020, 91 (4), pp.043903. 10.1063/1.5137740 . hal-02569809

\section{HAL Id: hal-02569809 \\ https://hal.science/hal-02569809}

Submitted on 11 May 2020

HAL is a multi-disciplinary open access archive for the deposit and dissemination of scientific research documents, whether they are published or not. The documents may come from teaching and research institutions in France or abroad, or from public or private research centers.
L'archive ouverte pluridisciplinaire HAL, est destinée au dépôt et à la diffusion de documents scientifiques de niveau recherche, publiés ou non, émanant des établissements d'enseignement et de recherche français ou étrangers, des laboratoires publics ou privés. 


\title{
Boron-MgO composite as an $\mathrm{X}$-ray transparent pressure medium in the multi-anvil apparatus
}

\author{
Longjian Xie ${ }^{1,2^{*}}$, Akira Yoneda ${ }^{1}$, Fang Xu ${ }^{3}$, Yuji Higo ${ }^{4}$, Chao Wang ${ }^{5}$, \\ Yoshinori Tange $^{4}$, Andrew King ${ }^{6}$, Daniele Antonangeli ${ }^{3}$, Guillaume Morard ${ }^{3,7}$, \\ Nicolas Guignot ${ }^{6}$ \\ 1. Institute for Planetary Materials, Okayama University, Misasa, Tottori 682-0193, \\ Japan \\ 2. Bayerisches Geoinstitut, University of Bayreuth, Bayreuth,95440, Germany \\ 3. Sorbonne Université, Muséum National d'Histoire Naturelle, UMR CNRS 7590, Institut \\ de Minéralogie, de Physique des Matériaux, et de Cosmochimie (IMPMC), 75005 Paris, \\ France
}

4. Japan Synchrotron Radiation Research Institute, 1-1-1 Kouto, Sayo, Hyogo 689-5198, Japan

5. State Key Laboratory of Geological Processes and Mineral Resources, China University of Geosciences, Wuhan 430074, China

6. Synchrotron SOLEIL, L'Orme des Merisiers, Saint-Aubin BP48, 91192 Gif-sur-Yvette, France

7. ISTerre, Université Grenoble Alpes, Université Savoie Mont Blanc, CNRS, IRD, IFSTTAR, F-38000 Grenoble, France

*Corresponding author. Tel: +49 (0)921 55 3743; Fax: +49 (0)921 553769

E-mail: ddtuteng@gmail.com 
Abstract:

X-ray transparent material is very beneficial for in-situ X-ray experiments in the multi-anvil apparatus. We sintered machinable blocks of boron-MgO composite at $800-1000{ }^{\circ} \mathrm{C}$ under atmospheric pressure from a mixture of amorphous boron and brucite or $\operatorname{Mg}(\mathrm{OH})_{2}$. Machinability of composite blocks improved with increasing brucite content in starting material; brucite content higher than 15 wt.\% showed reasonable machinability in forming various shapes such as octahedron, cylinder, and sleeve. We confirmed feasibility of the boron-MgO pressure medium through successfully generating lower mantle pressure $(>23 \mathrm{GPa})$; its pressure generation efficiency is comparable to that of $\mathrm{Cr}_{2} \mathrm{O}_{3}$ doped $\mathrm{MgO}$ pressure medium. The boron- $\mathrm{MgO}$ composite is expected to be an excellent thermal insulator owing to extremely low thermal conductivity of amorphous boron; we confirmed its better performance of thermal insulating through a comparative heating test with zirconia sleeve in $\mathrm{Cr}_{2} \mathrm{O}_{3}$ doped $\mathrm{MgO}$ pressure medium. Constituting light elements, the boron-MgO composite has high X-ray transparency, which enables us to conduct various cutting edge X-ray measurements in large volume multi-anvil apparatus.

Key words: boron- $\mathrm{MgO}$ composite, pressure medium, thermal insulator, $\mathrm{X}$-ray transparency, synchrotron X-ray, multi-anvil apparatus 


\section{INTRODUCTION}

High-pressure and high-temperature (HPHT) experiment is an indispensable means to understand the Earth's interior ${ }^{1}$. Diamond anvil cell (DAC) and Kawai-type multi-anvil apparatus (KMA) are two complementary apparatus to generate HPHT conditions. Comparing them, KMA can generate pressures in a much larger volume ${ }^{1,2}$, and thus has been widely used in various X-ray measurements revealing physical and chemical properties of minerals under Earth mantle conditions ${ }^{1,3}$.

There were remarkable breakthroughs in KMA recently: the highest pressure exceeded $100 \mathrm{GPa}$ by using sintered diamond anvils ${ }^{4,5}$, and the highest temperature reached as high as $4000 \mathrm{~K}$ by developing the boron-doped diamond (BDD) heating element ${ }^{6}$. Along with these developments, devising X-ray transparent cell in KMA is important as well in enhancing quality and capability of HPHT X-ray study. We demonstrated that BDD is an excellent heating material with high X-ray transparency ${ }^{6,7}$. However, transparent pressure medium, thermal insulator, and gasket are demanded as well to achieve high X-ray transparency in KMA experiment.

Chromium doped $\mathrm{MgO}\left(\sim 5\right.$ wt. $\left.\% \mathrm{Cr}_{2} \mathrm{O}_{3}\right)$ have been widely used as pressure medium in KMA experiments owning to its excellent efficiency in pressure generation. The X-ray transparency of $\mathrm{MgO}$ pressure medium decreases with decreasing X-ray energy. The attenuation coefficient becomes too large in the low energy range (especially, $<40 \mathrm{keV}$ ), and makes it difficult to measure high angle diffraction and X-ray spectroscopy such as X-ray absorption near-edge structure (XANES) spectroscopy. Furthermore, it has high thermal conductivity and a thermal insulator, usually X-ray opaque such as $\mathrm{ZrO}_{2}$, is commonly placed outside of heater to reduce the heat flow.

Since amorphous boron is more X-ray transparent and better thermal insulating than $\mathrm{MgO}$, boron-epoxy mixture has been frequently used as pressure medium for X-ray spectroscopy experiments ${ }^{\text {e.g. } 8}$. However, it has been recognized many disadvantages of using boron-epoxy mixture, such as limited pressure range (practically $<10 \mathrm{GPa}$ ), enhancing blow-out probability, and dehydrated water from epoxy. Under this context, we developed a boron- $\mathrm{MgO}$ composite pressure medium, which is free from these problems. We confirmed 

measurements.

\section{EXPERIMENTS}

A. Synthesis of machinable boron-MgO composite block
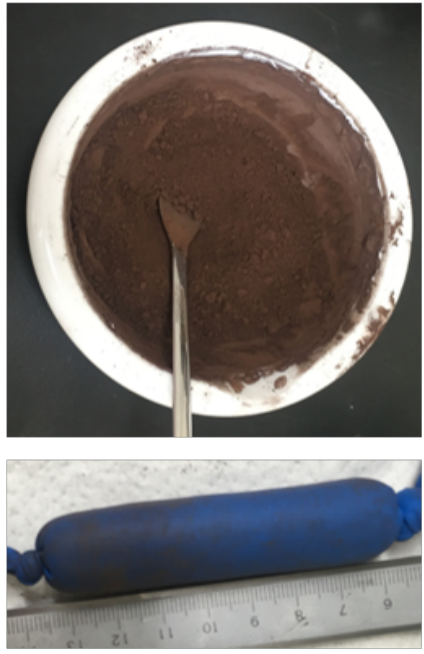

Mixing and filling in a rubber tube

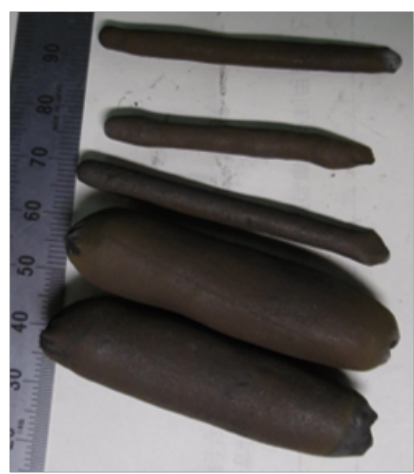

After Baking

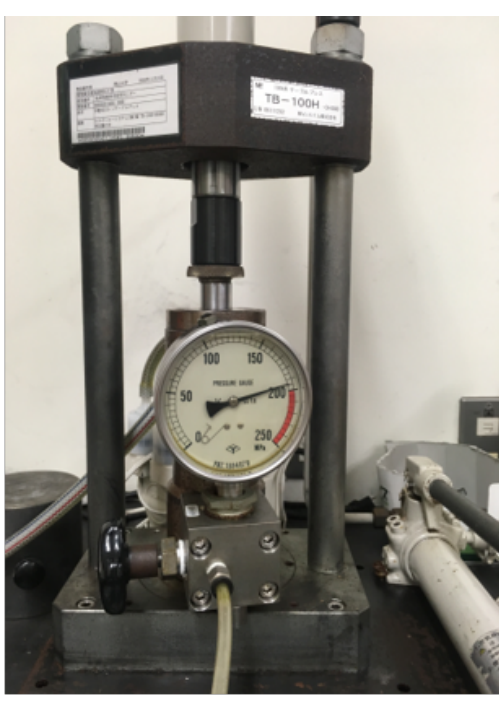

CIP to $200 \mathrm{MPa}$

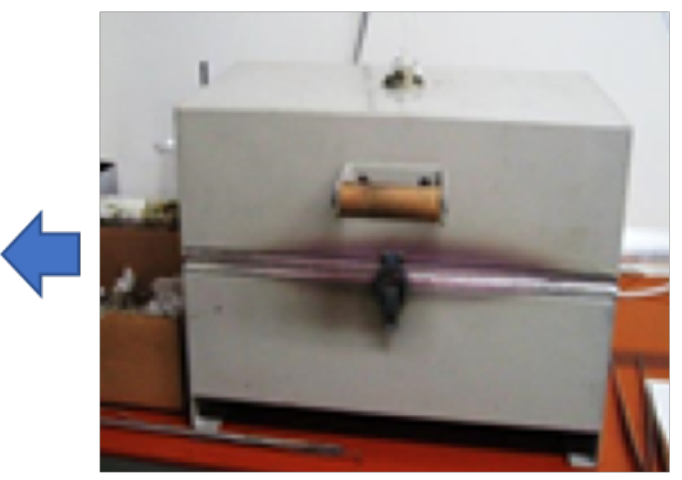

Baking in $\mathrm{Ar}+1 \% \mathrm{H}_{2}$ gas

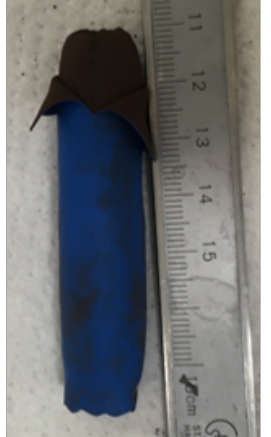

After CIP
79

FIG. 1. Procedure for making boron-MgO composite blocks.

As a starting material, commercial amorphous boron of $97 \%$ purity with a grain size of 0.8-1.4 $\mu \mathrm{m}$ and brucite of $95 \%$ purity with a grain size of $\sim 1 \mu \mathrm{m}$, were used. Figure 1 shows the procedure of making boron-MgO composite blocks. Amorphous boron and brucite powders with appropriate weight ratios, were hand-grounded with ethanol for 3 hours using a 
$\mathrm{Al}_{2} \mathrm{O}_{3}$ mortar and pestle. The mixture was then loaded in rubber balloons with diameter $\sim 20$ $\mathrm{mm}$, and cold isotropic pressed using a water-based liquid medium at ambient temperature to $200 \mathrm{MPa}$. After removing rubber from molded pieces, they were heated to $1000{ }^{\circ} \mathrm{C}$ with a heating rate of $3{ }^{\circ} \mathrm{C} / \mathrm{min}$ and baked at $1000{ }^{\circ} \mathrm{C}$ for $5-10$ hours in a $\mathrm{MgO}$ container inside a tubular maffle furnace (outer/inner diameter: $30 / 26 \mathrm{~mm}$ ) with a $\mathrm{Ar}+1 \mathrm{Vol} \% \mathrm{H}_{2}$ gas flow (flow rate: $50 \mathrm{ml} / \mathrm{min}$ ). Argon gas containing hydrogen was expected to reduce oxidation of boron. The decomposition temperature of brucite is between 472 and $1000{ }^{\circ} \mathrm{C}$ with a heating rate of $5.4^{\circ} \mathrm{C} / \mathrm{min}^{9}$, while the crystallization temperature of amorphous boron is higher than $1150{ }^{\circ} \mathrm{C}^{9}$. To ensure the complete decomposition of brucite and prevent the crystallization of amorphous boron, we baked the mixture at $1000{ }^{\circ} \mathrm{C}$. Therefore, brucite is expected to sinter the mixture when it decomposes to $\mathrm{MgO}$. We sintered boron- $\mathrm{MgO}$ composites with different weight ratio of boron and brucite $(90: 10,85: 15,50: 50)$ to examine their properties systematically. In this article, we specify boron-MgO composites using their boron weight ratios, such as B90.

The phases were identified by a micro-focused X-ray diffractometer. The sintered blocks were checked by scanning electron microscope. An octahedral shape of composite blocks was grinded using an automatic surface grinder (Okamoto, 52DX). A tube shape was machined using a lathe.

\section{B. Testing experiments in multi-anvil apparatus}

To check the properties of boron-MgO composite, such as efficiency of pressure generation, thermal conductivity, and X-ray transparency, we conducted HPHT experiments using them as pressure medium in multi-anvil apparatus (table 1).

The synchrotron X-ray experiments were conducted at Psiché (SOLEIL, France) or BL04B1(SPring-8, Japan) beamlines, while the offline experiments were conducted in Institute for Planetary Materials (IPM), Okayama University, Japan and in Bayerisches Geoinstitut, University of Bayreuth, Germany. 
114 TABLE 1. Summary of testing experiments. The prefixes " $1 \mathrm{k}$ ", " $5 \mathrm{k}$ " and " $\mathrm{H}$ " in the run 115 numbers correspond to the 1000-ton, 5000-ton and 6-axis presses installed at the Institute for 116 Planetary Materials (Okayama University), respectively; that of " $\mathrm{S}$ " corresponds to the 117 SUMITOMO press at Bayerisches Geoinstitut; that of "M" corresponds to the SPEED-MK.II 1500 press at the SPring-8 synchrotron facility; and that of "MA" corresponds to the Multi-anvil press at SOLEIL synchrotron facility.

\begin{tabular}{|c|c|c|c|c|}
\hline \multicolumn{5}{|c|}{ Experiments for Testing Thermal Efficiency } \\
\hline Run No. & Thermal Insulator & Sample & $\mathbf{P} / \mathbf{G P a}$ & $\mathbf{T} /$ \\
\hline $1 \mathrm{k} 2684$ & B90 & Amorphous C + B (3 wt.\%) & 15 & $\sim 2000$ \\
\hline S7478 & B85 & Graphite + B (3 wt.\%) & 15 & 1400 \\
\hline $1 \mathrm{k} 2707$ & $\mathrm{MgO}$ & Graphite + B (1 wt.\%) & 15 & 1900 \\
\hline $1 \mathrm{k} 2708$ & $\mathrm{ZrO}_{2}(0 \mathrm{Z} 8 \mathrm{C})$ & Graphite + B (1 wt.\%) & 15 & 1900 \\
\hline \multicolumn{5}{|c|}{ Experiments for Testing Pressure Generation Efficiency } \\
\hline Run No. & Cell assembly & Anvil Material & $\begin{array}{l}\text { Pressure } \\
\text { Medium }\end{array}$ & Sample \\
\hline MA15 & $10 / 4$ & TF05 WC & $\mathrm{MgO}$ & $\mathrm{MgO}+\mathrm{Au}(10 \mathrm{wt} . \%)$ \\
\hline MA11 & $10 / 4$ & TF05 WC & B85 & $\mathrm{MgO}+\mathrm{Au}(10 \mathrm{wt} . \%)$ \\
\hline $\mathbf{H 4 4 3}$ & $5 / 1.5$ & TF05 WC & B85 & $\mathrm{ZnS}$ \\
\hline H444 & $5 / 1.5$ & TF05 WC & B85 & $\mathrm{GaP}$ \\
\hline $\mathbf{H 4 4 5}$ & $5 / 1.5$ & Sintered Diamond & B85 & $\mathrm{ZnS}$ \\
\hline H452 & $5 / 1.5$ & Sintered Diamond & B85 & $\mathrm{GaP}$ \\
\hline \multicolumn{5}{|c|}{ Experiments for Checking $\mathrm{B}_{2} \mathrm{O}_{3}$ Problem } \\
\hline Run No. & Pressure Medium & Sample & $\mathbf{P} / \mathbf{G P a}$ & $\mathbf{T} /$ \\
\hline $5 \mathrm{~K} 3061$ & B85 & Forsterite & 19 & 1600 \\
\hline
\end{tabular}



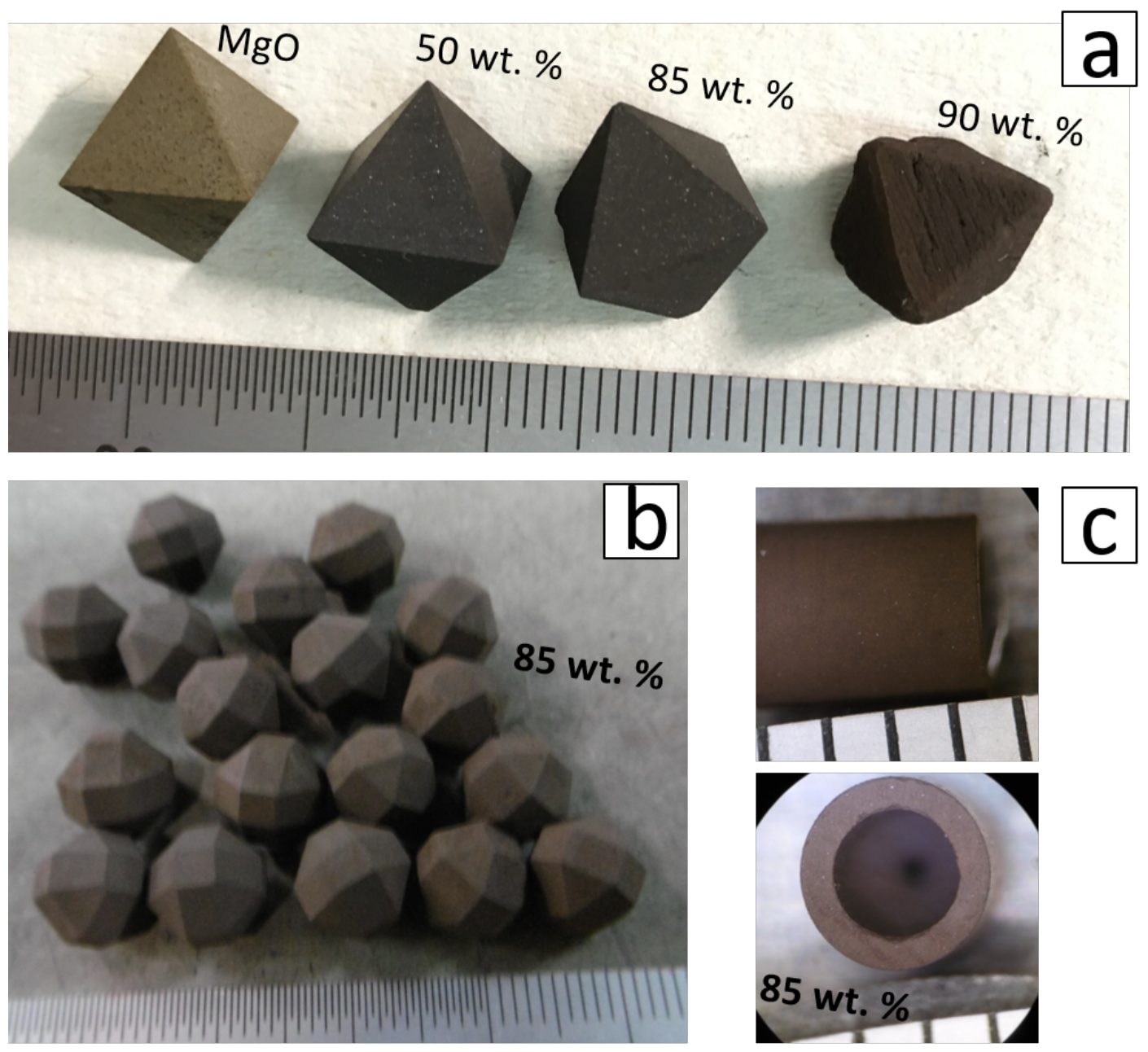

FIG. 2. Varies shapes machined from sintered B blocks. (a) Octahedra (10 mm edge length) machined from blocks with different boron contents. (b) Edges and vertexes truncated octahedra machined from B85. (c) Tube with $\mathrm{OD} / \mathrm{ID} / \mathrm{L}$ of 3.0/2.0/4.0 mm (OD: outer diameter, ID: inner diameter, L: length) machined from B85.

\section{RESULTS AND DISCUSSION}

\section{A. Machinability concept and characterization}

First concern on boron-MgO composite was its machinability (Fig. 2). Figure 2a shows octahedrons of boron- $\mathrm{MgO}$ composite as a function of boron contents. Higher boron content decreases the machinability of boron- $\mathrm{MgO}$ composite. Boron- $\mathrm{MgO}$ composite can be easily shaped into an octahedral shape by plate grinder when its boron content is lower than or equal to $85 \mathrm{wt} . \%$. On the other hand, higher boron content is desirable for high X-ray transparency and thermal insulation. Thus, we assumed B85 is the best composition from viewpoints of 
machinability, X-ray transparency, and thermal insulation. Therefore, our further characterization and test experiments were mainly conducted on B85.

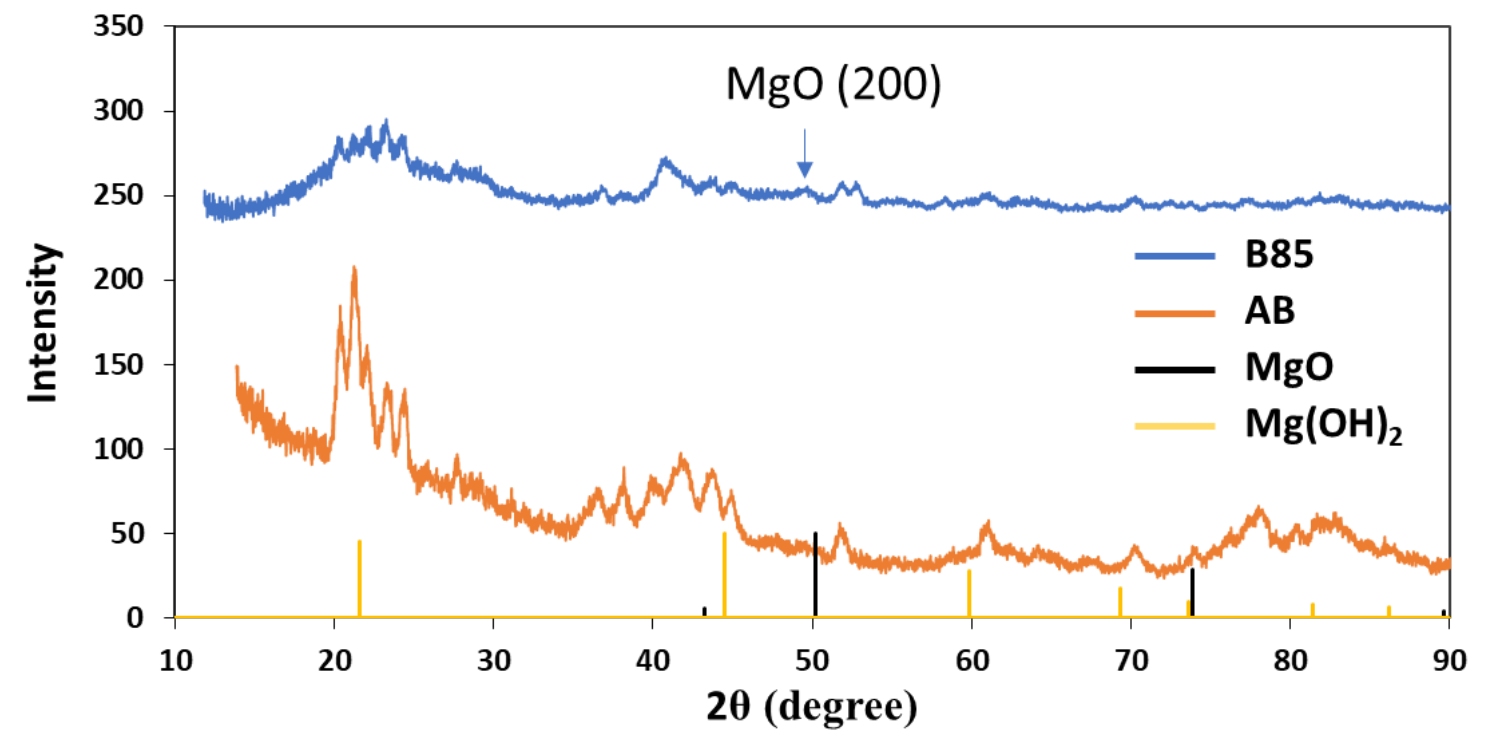

FIG. 3. X-ray diffraction patterns of the sintered B85. AB: commercial Amorphous boron. The profiles of $\mathrm{B} 85$ and $\mathrm{AB}$ were measured in this study; the X-ray beams with a wavelength of $1.79026 \AA$ were focused to $50-100 \mu \mathrm{m}$ using an IFG polycapillary X-ray mini-lens. The profiles of $\mathrm{MgO}$ and $\mathrm{Mg}(\mathrm{OH})_{2}$ were calculated according to d spacing (ICDD 4-829) in the international center of diffraction data (ICDD) and R040077.1 in RRUFF database.

Figure 3 compares the micro-focused X-ray diffraction pattern of commercial amorphous boron and boron- $\mathrm{MgO}$ composites. The commercial amorphous boron shows a series of weak sharp peaks, indicating its partially crystalline nature. Partially crystalline is a common phenomenon of commercial amorphous boron ${ }^{\text {e.g.10 }}$. B85 composite shows broad peaks, similar with those of amorphous boron, which suggests that amorphous boron did not crystallize significantly during baking. A small peak of $\mathrm{MgO}$ is identified from the $\mathrm{X}$-ray pattern of B85. Figure 4 shows backscattered electron images of B85. We can recognize that patches of $\mathrm{MgO}$ aggregate are homogeneously distributed in the amorphous boron matrix (Fig. 4a), and particle size of boron is $2-5 \mu \mathrm{m}$ (Fig. 4b). 


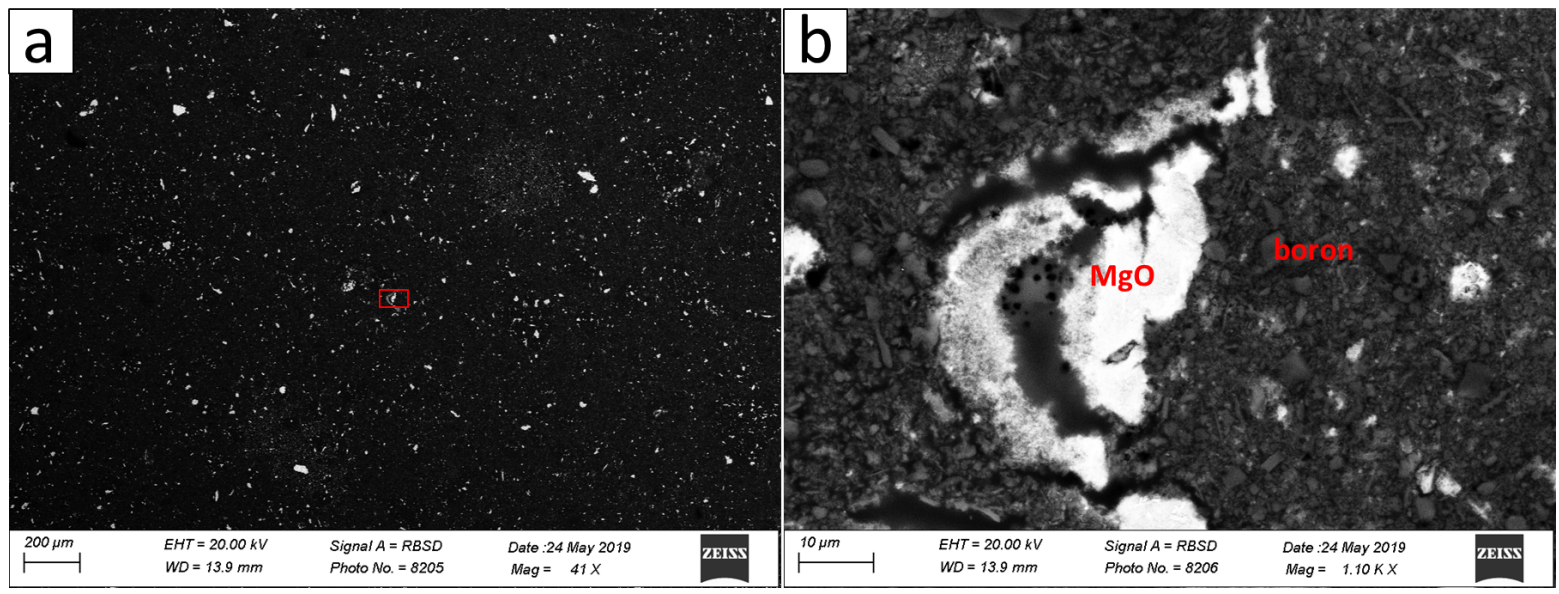

FIG. 4 Backscattered electron images of sintered B85 block. (b) Magnified image of rectangle area in (a).

\section{B. Pressure and temperature generation}
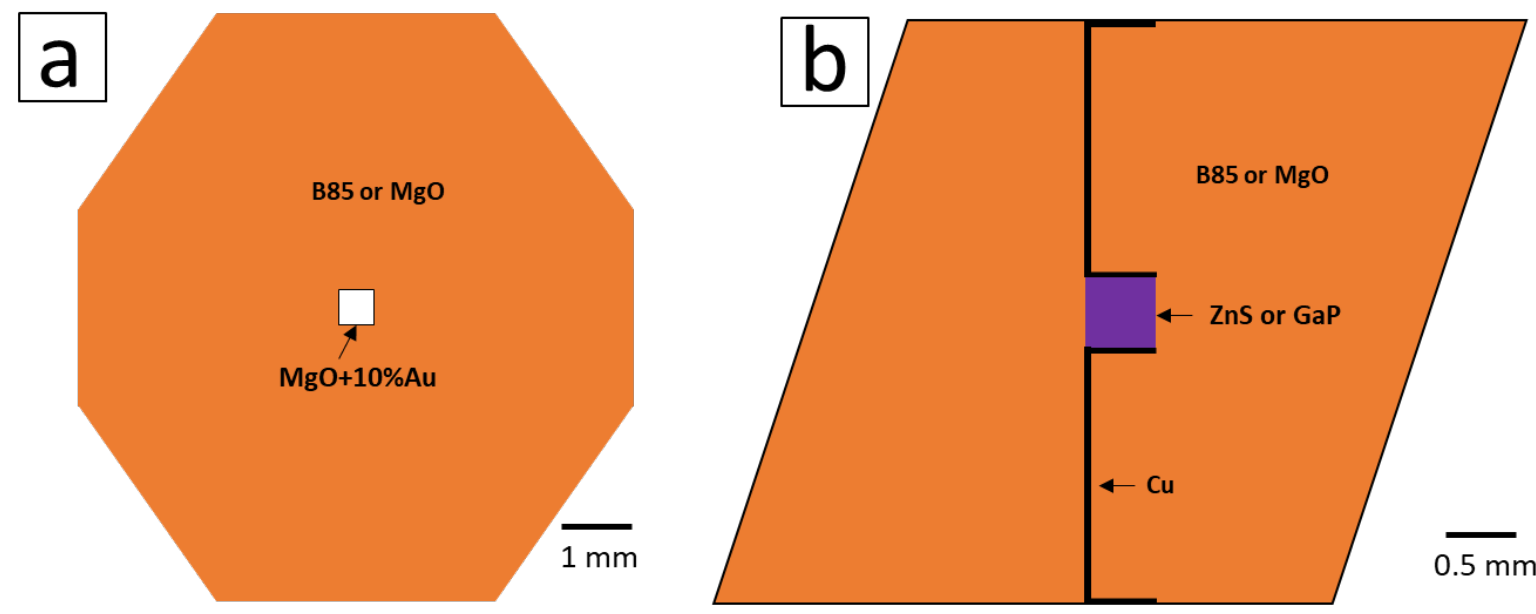

FIG. 5. Cell assemblies for testing pressure generation efficiency of B85 PM. (a), Cell assembly used at SOLEIL synchrotron facility. WC cubes (TF05) with $26 \mathrm{~mm}$ edge length were used as second stage anvils. The edge length of anvil truncation is $4 \mathrm{~mm}$. $\mathrm{MgO}$ or B85 octahedron with $10 \mathrm{~mm}$ edge length were used as PM. The edges and vertexes of octahedron were truncated. Pyrophilite with $4 \mathrm{~mm}$ width was used as gasket. A mixture of $\mathrm{MgO}+10$ wt.\% Au was used as pressure marker. (b), Cell assembly used in off line test experiment with 6-axis press at IMP. WC cubes (TF05) or sintered diamond cubes with $14 \mathrm{~mm}$ edge length were used as second stage anvils. The edge length of truncation is $1.5 \mathrm{~mm}$. $\mathrm{MgO}$ or $\mathrm{B} 85$ 
octahedron with $5 \mathrm{~mm}$ edge length were used as PM. $\mathrm{ZnS}$ or GaP were used as sample. The pressure was determined through the phase transition of sample, detected through a sudden decrease of sample electrical resistance.

Figure 5 shows the cell assemblies for pressure generation tests with and without using synchrotron X-ray. As shown in Fig. 6, we confirmed that B85 has similar efficiency with $\mathrm{MgO}$ in pressure generation no matter with $\mathrm{WC}$ or sintered diamond anvils; we succeeded in generating lower mantle pressures $(>23 \mathrm{GPa})$ with $\mathrm{B} 85$.
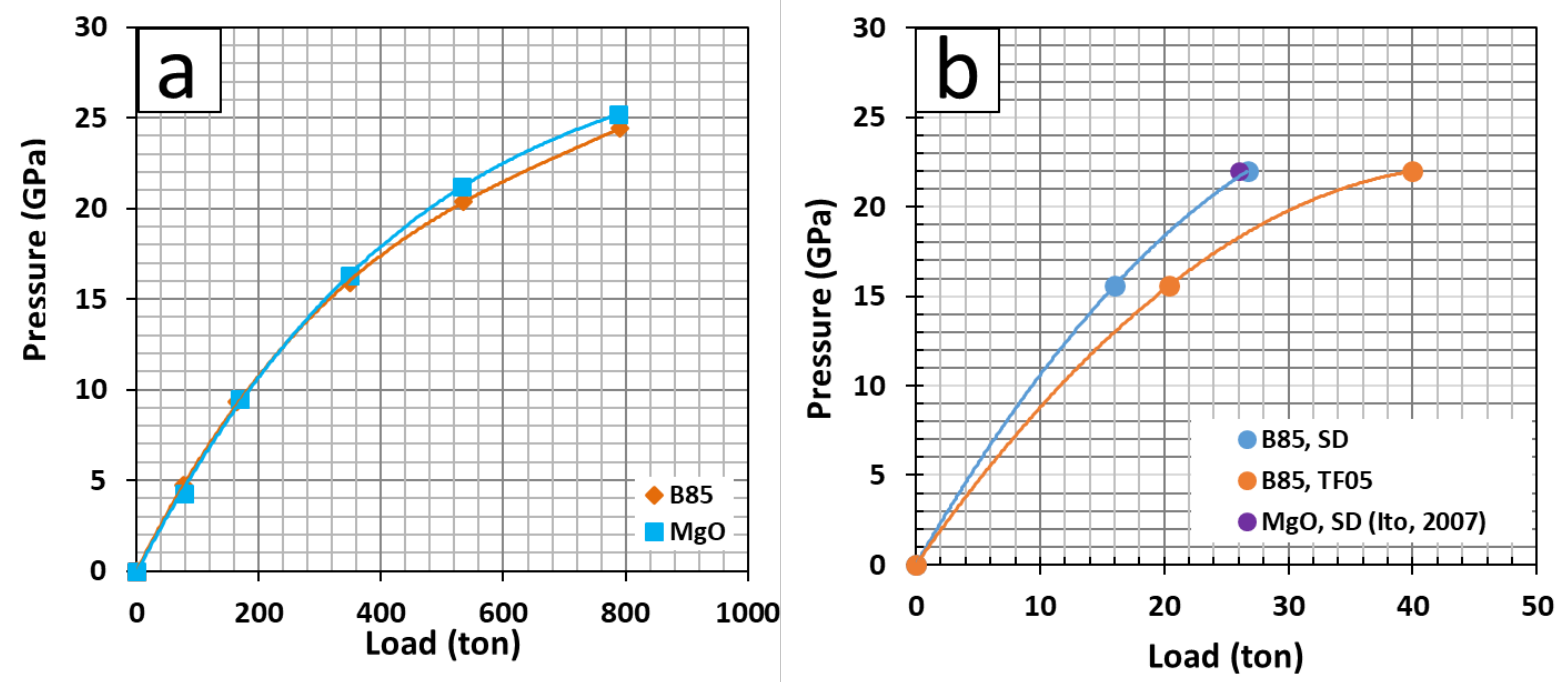

FIG. 6. Load-pressure relation with B85 PM in varies cells. (a), Load-pressure relation using cell of Fig. 5a. (b), Load-pressure relation using cell of Fig. 5b; SD: sintered diamond anvils; TF05: TF05 type of WC anvils.

Figure 7a shows the cell assembly for testing thermal insulation efficiency of B90 and B85. Cells were, firstly, compressed to $\sim 15 \mathrm{GPa}$ at room temperature. Then, temperatures were increased. Thermocouple failed at $1600,1400,1900$ and $1800{ }^{\circ} \mathrm{C}$, respectively, in the cells using $\mathrm{B} 90, \mathrm{~B} 85$, zirconia, and $\mathrm{MgO}$ as an insulator. Figure $7 \mathrm{~b}$ shows the power-temperature relationship with different thermal insulating materials. B90 and B85 insulators have similar thermal insulating efficiency, which are comparable to zirconia insulator, but much more efficient than $\mathrm{MgO}$ insulator. 


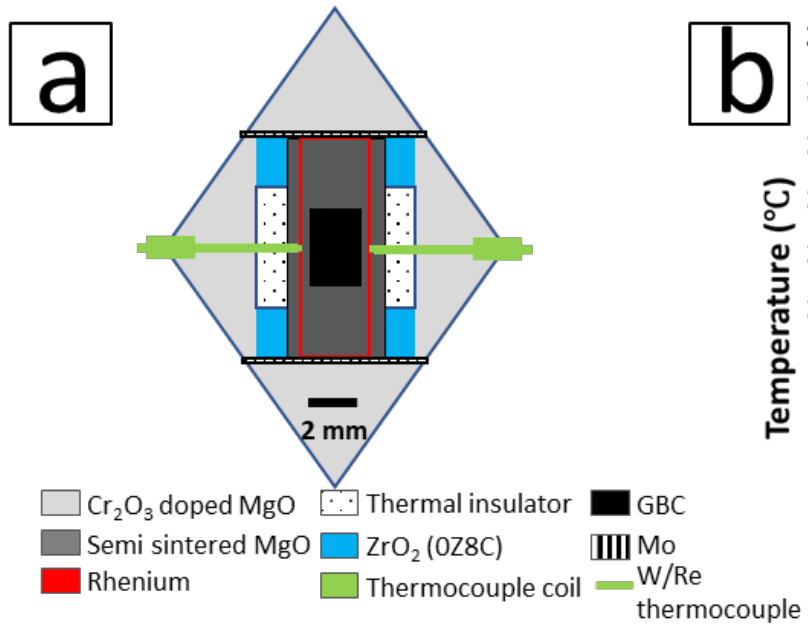

189

190

It is known that $\mathrm{B}_{2} \mathrm{O}_{3}$ is an important flux for silicate and oxides, which helps to decrease melting temperature significantly. We experienced the effect during the development of graphite-boron composite $(\mathrm{GBC})$ heater ${ }^{11}$. A small amount of $\mathrm{B}_{2} \mathrm{O}_{3}$ may form during sintering boron- $\mathrm{MgO}$ composite even though in the atmosphere of $\mathrm{Ar}+1 \% \mathrm{H}_{2}$. To check the $\mathrm{B}_{2} \mathrm{O}_{3}$ effect, we did a testing experiment at $1600{ }^{\circ} \mathrm{C}$ and $\sim 19 \mathrm{GPa}$ using forsterite sample (Fig. $8 \mathrm{a})$. Figure $8 \mathrm{~b}$ shows the recovered sample. Forsterite converted to Wd without abnormal melt. Unlike using GBC heater directly contacting with sample, Re heater and surrounding $\mathrm{MgO}$ sleeve seem to work an efficient barrier against $\mathrm{B}_{2} \mathrm{O}_{3}$ reacting with sample. 

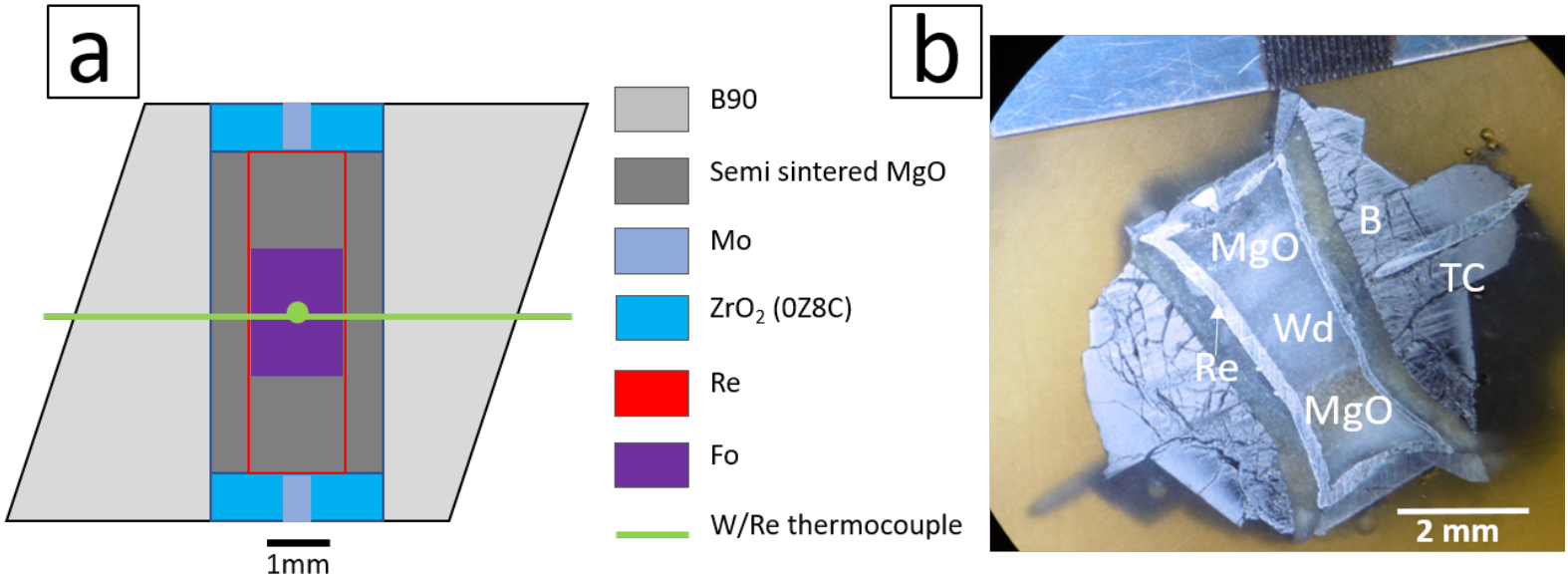

FIG. 8. (a) Cell assembly for checking $\mathrm{B}_{2} \mathrm{O}_{3}$ problem and (b) microscope image of recovered sample. Fo: forsterite, Wd: Wadsleyite, TC: thermocouple.

\section{X-ray transparency}

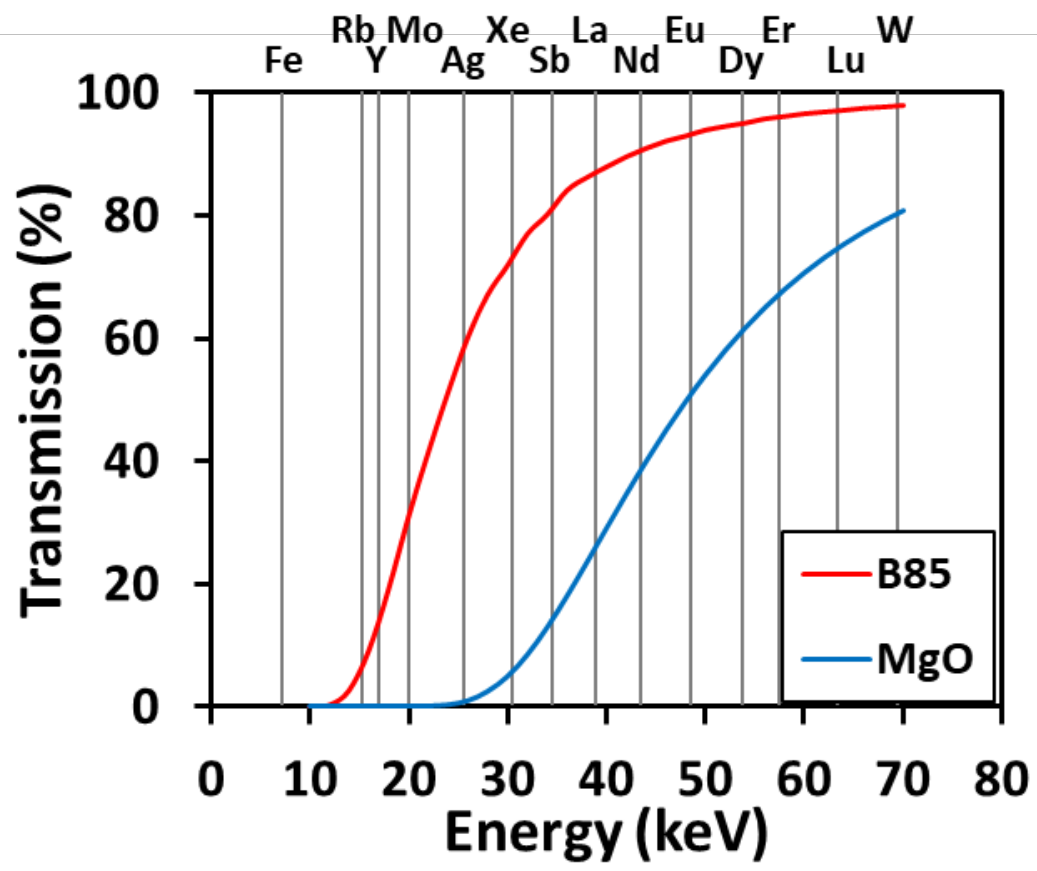

FIG. 9. Calculated X-ray transmission of $\mathrm{B} 85$ and $\mathrm{MgO}$ with a sample length of $20 \mathrm{~mm}$.

Element symbols and corresponding black lines mark energy of their characteristic X-ray.

The packing fraction is 0.6 . The calculation was done using public web unity by Robert et al. $2013^{12}$, based on python software package Absorb. 
High X-ray transparency of PM, especially in low energy range, is very beneficial in various X-ray imaging, scattering and absorption measurements (e.g. structural analysis of non-crystal materials using X-ray diffraction method and XANES). Figure 9 compares the $\mathrm{X}$-ray transparency between $\mathrm{B} 85$ and $\mathrm{MgO}$ blocks. Owing to smaller atomic number of boron than $\mathrm{Mg}$ and $\mathrm{O}, \mathrm{B} 85$ has higher X-ray transparency than $\mathrm{MgO}$, especially at low energy range from 15 to $70 \mathrm{keV}$. Therefore, PM made of B85 has great advantage for various X-ray imaging, scattering and absorption measurements, especially in low energy range.
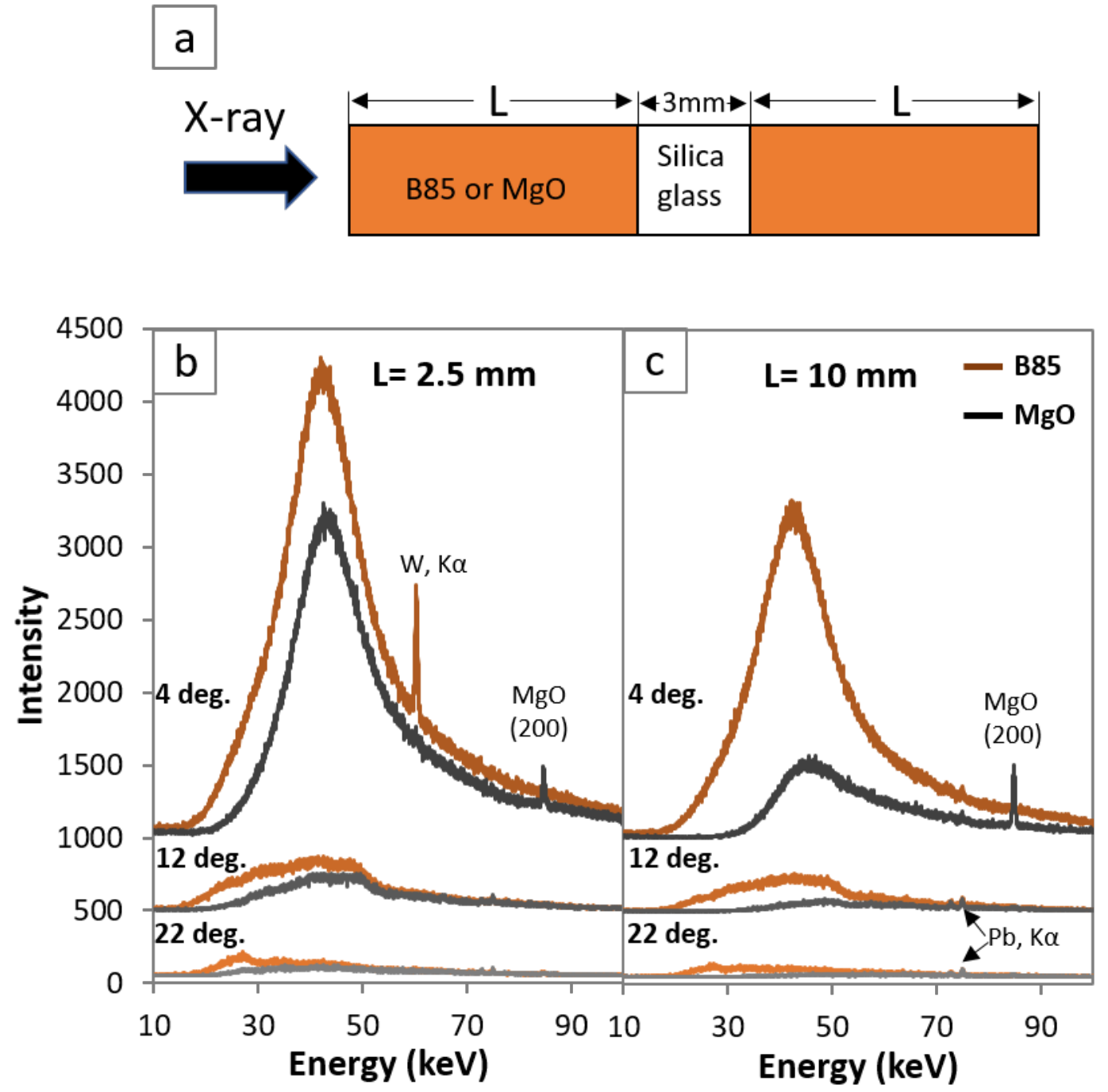

FIG. 10. Assembly and result of X-ray diffraction test. (a) Schematic sketch of X-ray passage for testing X-ray diffraction test. (b) and (c) signal of X-ray diffraction at varies 2 theta and X-ray energy for cell assemblies with $\mathrm{L}=2.5 \mathrm{~mm}$ and $10 \mathrm{~mm}$, respectively. The cell assemblies were placed on the top of WC anvils. An X-ray beam with size of $0.1 \mathrm{~mm}$ in horizontal and $0.2 \mathrm{~mm}$ in vertical direction, was used for obtaining the energy dispersed 
X-ray (EDX) patterns of silica glass at SPring-8. The EDX patterns were obtained with 600s exposure time at 4, 12 and 22 degrees by a Ge solid state detector. deg. is short for degree.

To confirm the better performance of B85 block, we did X-ray diffraction testing experiments using silica glass as sample (Fig. 10). Figure 10a shows the schematic sketch of $\mathrm{X}$-ray passage. A silica glass rod with $3 \mathrm{~mm}$ diameter was place in the center of $\mathrm{B} 85$ or $\mathrm{MgO}$ block. Since the X-ray absorption coefficient of elements is almost independent with pressure, the test was conducted at ambient pressure. To simulate the conditions of different cell sizes, we checked the X-ray diffraction data using assemblies with 8 and $23 \mathrm{~mm}$ total lengths. Figure $10 \mathrm{~b}$ and $\mathrm{c}$ shows the results. The signal of sample using B85 block is obviously higher than that using $\mathrm{MgO}$ block, especially at low energy range. The signal is almost undetectable using $\mathrm{MgO}$ block for energy lower than $30 \mathrm{keV}$. The signal with $8 \mathrm{~mm} \mathrm{MgO}$ assembly ( $3 \mathrm{~mm}$ sample $+5 \mathrm{~mm} \mathrm{MgO}$ ) is comparable with that of $23 \mathrm{~mm} \mathrm{B85}$ assembly (3

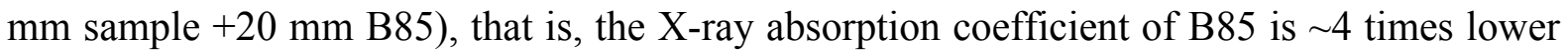
than that of $\mathrm{MgO}$. The signal of diffraction decreases quickly with increasing 2theta angle. Thus, $\mathrm{B} 85$ has an advantage over $\mathrm{MgO}$ for high angle diffractions.
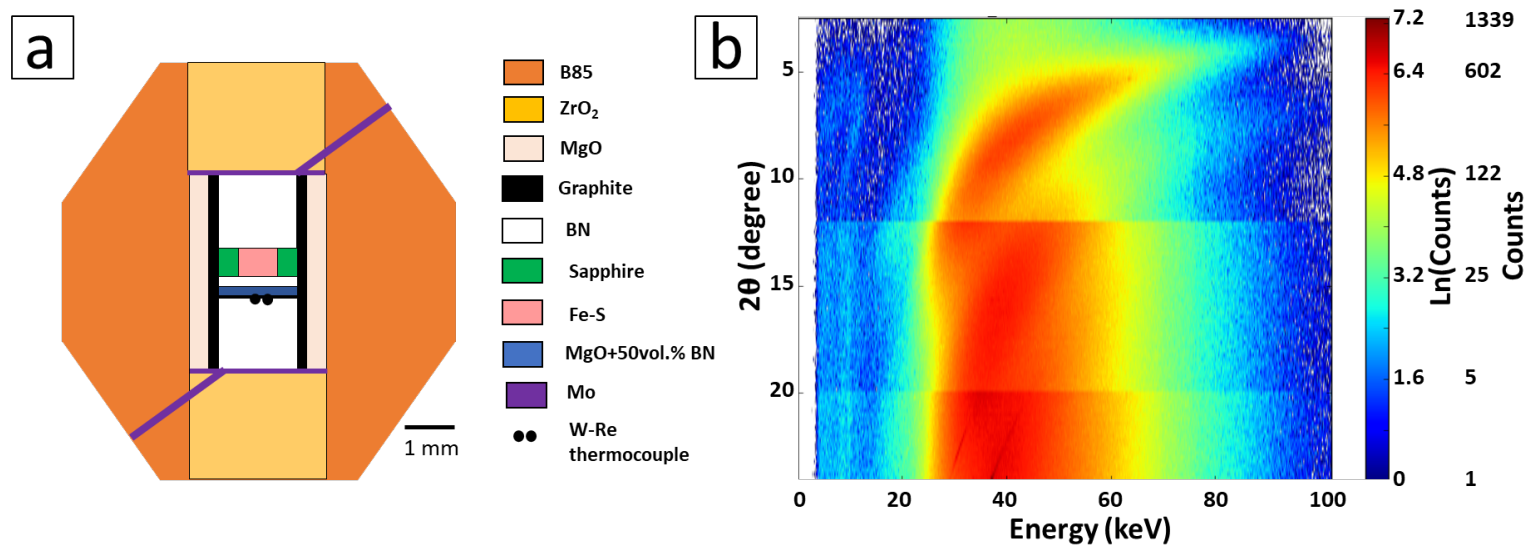

FIG. 11. (a) Cell assembly for testing X-ray transparency and (b) 2D image of X-ray diffraction intensity at varies 2 theta and X-ray energy. A focused X-ray beam was used for obtain the EDX patterns of melt at Psiché, SOLEIL. The EDX patterns were obtain by a Ge solid state detector with a step angle of 0.2 degree. Diffraction time of 5, 10 and 20 seconds per pattern were used for angle ranges from 2.5 to 12 , from 12 to 20 and from 20 to 25 degree, respectively. 
Figure 11a shows an assembly for testing the performance of B85-PM for structural analysis of melt using X-ray diffraction method. Figure $11 \mathrm{~b}$ is the results of X-ray scattering data of $\mathrm{Fe}-\mathrm{S}$ melt at $\sim 5 \mathrm{GPa}$; energy dispersed X-ray diffraction patterns were obtained from 2.5 to 25 degree with a step of 0.2 degree. Owing to highly transparency of B85-PM and B85-window in gasket, it was confirmed that 20 second measurement time is enough to acquire a fine pattern even at high angles (from 20 to 25 degree); the average diffraction time was $\sim 15$ seconds yielding the total diffraction time shorter than 25 minutes. Therefore, the better performance of B85-PM was demonstrated in X-ray scattering measurement in melt structure study.

\section{CONCLUSIONS AND PERSPECTIVES}

We succeeded in synthesizing boron-MgO composite blocks, exhibiting their machinability, and demonstrating their performance in HPHT X-ray study; among boron- $\mathrm{MgO}$ composites, we recommended B85 as most suitable for PM and gasket window. Consequently, we believe that B85 contributes to future X-ray study up to lower mantle conditions.

\section{ACKNOWLEDGEMENTS}

We would like to acknowledge Denis Andrault, Geeth Manthilake, and Daisuke Yamazaki for their help in experiments at SOLEIL synchrotron facility. We also acknowledge Chao Liu, Jaseem Vazhakuttiyakam, Noriyoshi Tsujino, Youyue Zhang, Hitoshi Gomi, Moe Sakurai for their help in experiments at SPring-8 synchrotron facility. We thank Tiziana Boffa Ballaran for the help on micro-focused X-ray diffraction analysis and Dorothea Wiesner for backscattered electron imaging. We thank Eiji Ito, Takashi Yoshino and Tomoo Katsura for constructive suggestions. The synchrotron radiation experiments were performed under SPring-8 Budding Researcher Support Program (Nos. 2017B1686 and 2018A1637) and SOLEIL research proposals (Nos. 20160333, 20170194 and 20170506). This work was supported by Grants-in-Aid for Scientific Research (Nos. 22224008 and $15 \mathrm{H} 02128$ to Akira Yoneda) and Research Fellowship for Young Scientists 
284 (DC2-JP17J10966 to Longjian Xie) from the Japan Society for the Promotion of Science. 285 This project has received funding from the European Research Council (ERC) under the 286 European Union's Horizon 2020 research and innovation programme (Grant agreement No. 287 724690). 


\section{REFERENCES}

290

${ }^{1}$ E. Ito, Treatise on Geophysics, Elsevier, edited by G. Schubert, B. Romanowicz, A.

Dziewonski (San Diego, 2007) vol. 2, pp. 197-230.

292

${ }^{2}$ D.J. Frost, B.T. Poe, R.G. Trønnes, C. Liebske, A. Duba and D.C. Rubie, Phys. Earth Planet In. 143, 507 (2004).

Sumiya, E. Ito and T. Katsura, Rev. Sci. Instrum. 80, 023907 (2009).

${ }^{4}$ D. Yamazaki, E. Ito, T. Yoshino, N. Tsujino, A. Yoneda, X. Guo, F. Xu, Y. Higo and K. Funakoshi, Phys. Earth Planet. In. 228, 262-267 (2014).

${ }^{5}$ D. Yamazaki, E. Ito, T. Yoshino, N. Tsujino, A. Yoneda, Gomi, H., J. Vazhakuttiyakam, M. Sakurai, Y. Zhang, Y. Higo, Y. Tange, C. R. Geosci., 351(2-3), 253-259(2019).

${ }^{6}$ L. Xie, A. Yoneda, T. Yoshino, D. Yamazaki, N. Tsujino, Y. Higo, Y. Tange, T. Irifune, T. Shinmei and E. Ito, Rev. Sci. Instrum. 88(9), 093904 (2017).

${ }^{7}$ L. Xie, A. Yoneda, D. Yamazaki, G. Manthilake, Y. Higo, Y. Tange, N. Guignot, A. King, M. Scheel and D. Andrault, Nat. Commun. 11, 548 (2020).

${ }^{8}$ O. Ohtaka, A. Yoshiasa, H. Fukui, K. Murai, M. Okube, H. Takebe, Y. Katayama and W. Utsumi. J. Phys. Condens. Matter. 14(44), 10521(2002).

${ }^{9}$ R. S. Gordon and W. D. Kingery. J. Am. Ceram. Soc. 49 (12), 654-660 (1966).

${ }^{10}$ S. O. Shalamberidze, G. I. Kalandadze, D. E. Khulelidze, and B. D. Tsurtsumia. J. Solid State Chem. 154(1), 199-203 (2000).

${ }^{11}$ L. Xie, A. Yoneda, T. Yoshino, H. Fei and E. Ito, High Press. Res. 36, 105-120 (2016).

${ }^{12}$ R. B. Von Dreele, M. R. Suchomel and B. H. Toby, Retrieved from https://11bm.xray.aps.anl.gov/absorb/absorb.php (2013). 